\title{
The Effectiveness of FLEMONIC to Improve Students' Information Retention Ability for the Electrolysis of Water
}

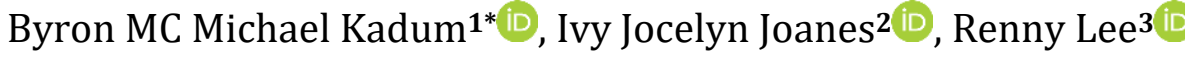 \\ ${ }^{1}$ Chemistry Unit, Department of Science, Labuan Matriculation College (LMC), OKK Daud Road, 87027 \\ Federal Territory of Labuan, Malaysia. \\ Email: byron@kml.matrik.edu.my \\ ${ }^{2}$ Chemistry Unit, Department of Science, Labuan Matriculation College (LMC), OKK Daud Road, 87027 \\ Federal Territory of Labuan, Malaysia. \\ Email: ivy@kml.matrik.edu.my \\ ${ }^{3}$ Chemistry Unit, Department of Science, Labuan Matriculation College (LMC), OKK Daud Road, 87027 \\ Federal Territory of Labuan, Malaysia. \\ Email: renny@kml.matrik.edu.my
}

\section{CORRESPONDING \\ AUTHOR (*):}

Byron MC Michael Kadum

(byron@kml.matrik.edu.my)

\section{KEYWORDS: \\ FLEMONIC \\ Flip-note \\ Mnemonic \\ Retention \\ Water electrolysis}

\section{CITATION:}

Kadum, B. MC. M., Joanes, I. J., \& Lee, R.. (2022). The Effectiveness of FLEMONIC to Improve Students'

Information Retention Ability for the

Electrolysis of Water. Malaysian Journal of

Social Sciences and Humanities (MJSSH),

7(2), e001310.

https://doi.org/10.47405/mjssh.v7i2.1310

\begin{abstract}
The teacher-researchers' past lesson reflections suggested that students were having difficulty in memorising the reaction equations involved in the discharging of $\mathrm{H}_{2} \mathrm{O}$ (l) for an electrolytic cell. Ergo, in the attempt to remedy the dilemma, the teacher-researchers materialised "FLEMONIC: Discharging of $\mathrm{H}_{2} \mathrm{O}$ (l)". It is an intervention that incorporated the elements of flip-note, mnemonic, and the concept of origami. A positivist conventional quasiexperimental method was utilised to investigate its effectiveness and data from an experimental group (17 students) and a control group (17 students) were collected. Both groups mark differences for the students' pre-test and post-test marks were quantitatively analysed by using IBM SPSS software. The outcome revealed that FLEMONIC did indeed significantly improve the experimental group's information retention ability whereby $p=0.003(p<0.05)$. In addition, the intervention managed to inspire the chemistry students to create their own FLEMONIC notes for topics in biology, computer science, mathematics, and physics. This had caused their note-taking and learning to be more fun and interesting both in chemistry and other subjects. To date, almost 700 Labuan Matriculation College students have had benefited from using FLEMONIC.
\end{abstract}

Contribution/Originality: This study documents the importance of developing students' lower-order thinking skills (LOTS) in chemistry. By helping students to memorise scientific facts in a more efficient way, it will facilitate the process to foster their higher-thinking skills (HOTS). Thus, it originates novel mnemonics in learning the electrolysis of water via FLEMONIC. 


\section{Introduction}

Addiction - for some, it carries a negative connotation as it is usually associated with persistent compulsive use of harmful substances such as drugs and alcohol. However, in a broader term, the noun is defined as an unusually great interest in something or a need to do or to have something (Merriam-Webster Online, n.d.). A passionate teacher possesses great interests in designing effective teaching and learning ecosystems. Perhaps, passion is conceptually equal to addiction. Carbonneau et al. (as cited in Mart, 2013) stated that passion is defined as a strong inclination or desire towards an activity that one likes and finds important, and in which one invests time and energy. Therefore, suffice to say that a passionate teacher is someone who has an addiction towards teaching and learning excellence.

The intention in developing this report goes beyond sharing the teacher-researchers' materialised lesson intervention. Hence, it is also a platform to illuminate their "good addiction" towards promoting a better learning experience for their chemistry students. This passion/addiction is not merely an abstract concept, but it is rather a neurological process. Neuroscience has reported the link between passion/addiction with pleasure. At the time when a person is experiencing "pleasure", the neurons at specific regions of his/her brain (e.g., nucleus accumbens, ventral pallidum and brainstem) are becoming active and biochemical such as dopamine (reward hormone) is filling his/her neurological system (Esch \& Stefano, 2004; Kringelbach \& Berridge, 2009).

Students' inability to memorise chemistry facts and figures is a major concern for the teacher-researchers. They have found that relying solely on a conventional didactic strategy is not going to remedy the situation effectively. Hence, driven by their passion/addiction they materialised FLEMONIC as a teaching and learning (T\&L) tool to help their students to improve their information retention ability.

\section{Literature Review}

Reflecting upon a lesson is equally important as planning the lesson itself. The purpose of reflection is to gain a better comprehension of an idea and therefore it may be restructured to amplify its effect (Moon, 2004). For the purpose of this study, the teacher-researchers re-analysed their lesson reflections and realised that their former students were having difficulty in information retention. The problem was primarily apparent when it came to the memorisation of chemical components in the reaction equations involved in the discharging of $\mathrm{H}_{2} \mathrm{O}(I)$ for an electrolytic cell. Based on the pattern they saw in their lesson reflections; it was assumed that their current students would showcase the same retention problem.

Chemistry in general is known as a complex field of knowledge. Individuals are expected to be mystified by the three levels of thought of the subject, i.e., the macro and tangible, the sub-micro atomic and molecular, and the representational use of symbols and mathematics (Johnstone, 2000). Moreover, the difficulty of learning chemistry is accentuated when declarative knowledge is taken into consideration. Like passion/addiction and pleasure, learning and memory are concepts that arise from neuronal activities (Leamnson, 2000; Kandel, 2001). Thus, according to neuroscience, declarative knowledge is understood to be a part of long-term memories formation in which the brain's medial temporal lobe diencephalon becomes active for this purpose. 
Declarative knowledge is associated with the conscious recalling of facts and knowledge (Squire \& Zola, 1996).

The problem identified by the teacher-researchers fell in the realm of recalling facts, i.e., information retention. SK025 (Chemistry 2) of the Chemistry SK015 \& SK025 Curriculum Specification (Matriculation Division, 2020) required the students to learn about "Electrolytic Cell" in Chapter 3: Electrochemistry. One of the learning outcomes expects students to be able to explain the electrolysis of $\mathrm{H}_{2} \mathrm{O}(l)$, dilute $\mathrm{NaCl}(a q)$ and $\mathrm{Na}_{2} \mathrm{SO}_{4}(a q)$ by using inert electrodes. To explain the electrolysis of those compounds adequately, the students must be able to memorise the components comprised in the reaction equations involved (refer to Figure 1). Hence, the degree of memorisation is overwhelming for students to cope.

Figure 1: Redox Equations for The Electrolysis of $\mathrm{H}_{2} \mathrm{O}(I)$

The Redox Equations for The Discharging of $\mathrm{H}_{2} \mathrm{O}$ (l) of An Electrolytic Cell:

Anode $\quad: 2 \mathrm{H}_{2} \mathrm{O}(\mathrm{l}) \rightarrow 4 \mathrm{e}^{-}+\mathrm{O}_{2}(\mathrm{~g})+4 \mathrm{H}^{+}(\mathrm{aq})$

Cathode $\quad: 2 \mathrm{H}_{2} \mathrm{O}(\mathrm{l})+2 \mathrm{e}^{-} \rightarrow \mathrm{H}_{2}(\mathrm{~g})+2 \mathrm{OH}^{-}(\mathrm{aq})$

Overall $: 2 \mathrm{H}_{2} \mathrm{O}(\mathrm{aq}) \rightarrow \mathrm{O}_{2}(\mathrm{~g})+2 \mathrm{H}_{2}(\mathrm{~g})$

Empowered by their passion/addiction, the teacher-researchers designed FLEMONIC in their effort to aid their students' information retention ability. FLEMONIC's design was based on the ideas of flip-note and mnemonic. Both are well-known strategies in helping users to remember facts and figures efficiently. "Remembering" is the lowest taxon in Bloom's cognitive domain (Forehand, 2010). The teacher-researchers understood that being as the lowest cognitive domain did not equate with being the least important. In fact, they perceived "remembering" as the basis of which their students were lacking, and it potentially implicated their ability to move up to higher-order cognitive domains. Ergo, FLEMONIC's design purpose was simple; to assist students in honing their remembering skills so that they would be better prepared for higher-order thinking domains.

\section{Methodology \& Implementation of FLEMONIC}

As an education research paradigm, positivism concerns the testing of theories and hypotheses. It mainly involves quantitative methodology, i.e., experimental methods are employed. Hence, a positivist teacher-researcher assumes an external observer role and administers pre- and post-tests to harvest data that will be analysed accordingly, e.g., by using software such as IBM SPSS (Aljandali, 2016).

For the current study, the teacher-researchers initiated the sampling stage by testing eighty-three (83) students from four (4) tutorial groups with the pre-test material (refer to Figure 2). The students had finished going through the lectures on "Electrolytic Cell" prior to the pre-test. The pre-test was done on the $11^{\text {th }}$ of January 2021 and the students were given fifteen (15) minutes to complete the test. To obtain a significant outcome 
from the quantitative analysis, the teacher-researchers shrunk the sampling pool by selecting 34 students who gained pre-test scores lesser than seven (7) out of thirteen (13). These were regarded as "fail scores" as they were lesser than 50\%. From there, the teacher-researchers assigned seventeen (17) students as the control group and seventeen (17) students as the experimental group.

Figure 2: Pre-Test \& Post-Test Material

\section{Quick Test: Water Electrolysis}

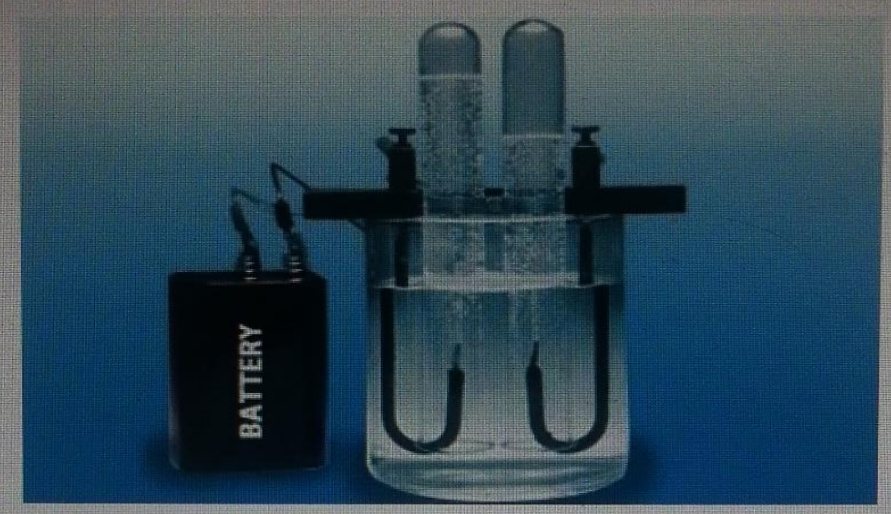

Water is an electro-active substance. It can be oxidised or reduced in an electrochemical process, depending on the conditions of electrolysis.

State the overall cell reaction equation, reduction half-equation, oxidation half-equation of water molecules:

The control group underwent a conventional didactic post-lecture tutorial lesson on the discharging of $\mathrm{H}_{2} \mathrm{O}(I)$ at cathode and anode of electrolytic cell and the experimental group learned the topic with the assistance of FLEMONIC. By the end of the T\&L sessions of respective groups, the students were told that they would be tested on the learned subject matter and the teacher-researchers instructed them to memorise the redox equations of the electrolysis. The experimental group was encouraged to utilise FLEMONIC to revise for the test and the control group was told to rely on the given materials from the conventional didactic lesson. After a week (on the $18^{\text {th }}$ of January 2021), both groups were tested (post-test) with the identical material administered during the pre-test and the groups were given the same amount of time for the post-test - fifteen (15) minutes.

For this investigation, the teacher-researchers posited a null hypothesis $\left(\mathrm{H}_{0}\right)$; "FLEMONIC: Discharging of $\mathrm{H}_{2} \mathrm{O}(I)$ " cannot strengthen chemistry students' declarative knowledge and thus it does not help the students to memorise the redox equations of $\mathrm{H}_{2} \mathrm{O}(I)$ electrolysis. As described in the previous paragraph, deliberate sampling was opted by the teacher-researchers for their classroom investigation as generalisation was not concerned. Deliberate sampling is usually implemented for achieving heterogeneity (Blankertz, 1998). Therefore, it was a suitable sampling technique for showing that FLEMONIC was indeed effective in improving their students' information retention ability. 


\subsection{FLEMONIC's Operating System}

FLEMONIC's operating system was designed based on the ideas of mnemonic and flipnote with a touch of origami influence. The FLEMONIC sets that were distributed to the experimental students after the pre-test was made from A4 sized papers folded into rectangular "flip-booklets" (refer to Figure 3). There were four (4) compartments of the FLEMONIC flip-booklet left with several blank spaces for the experimental students to fill in with appropriate answers (refer to Figure 9). For every compartment, the students were guided with instructions and mnemonics. Furthermore, every time they progressed to the next compartment; they would be provided with the correct answers to the previous compartment's blank spaces so that they could self-evaluate their answers. For the convenience of this report, the compartments are regarded as "FLEMONIC Compartments".

Figure 3: The FLEMONIC

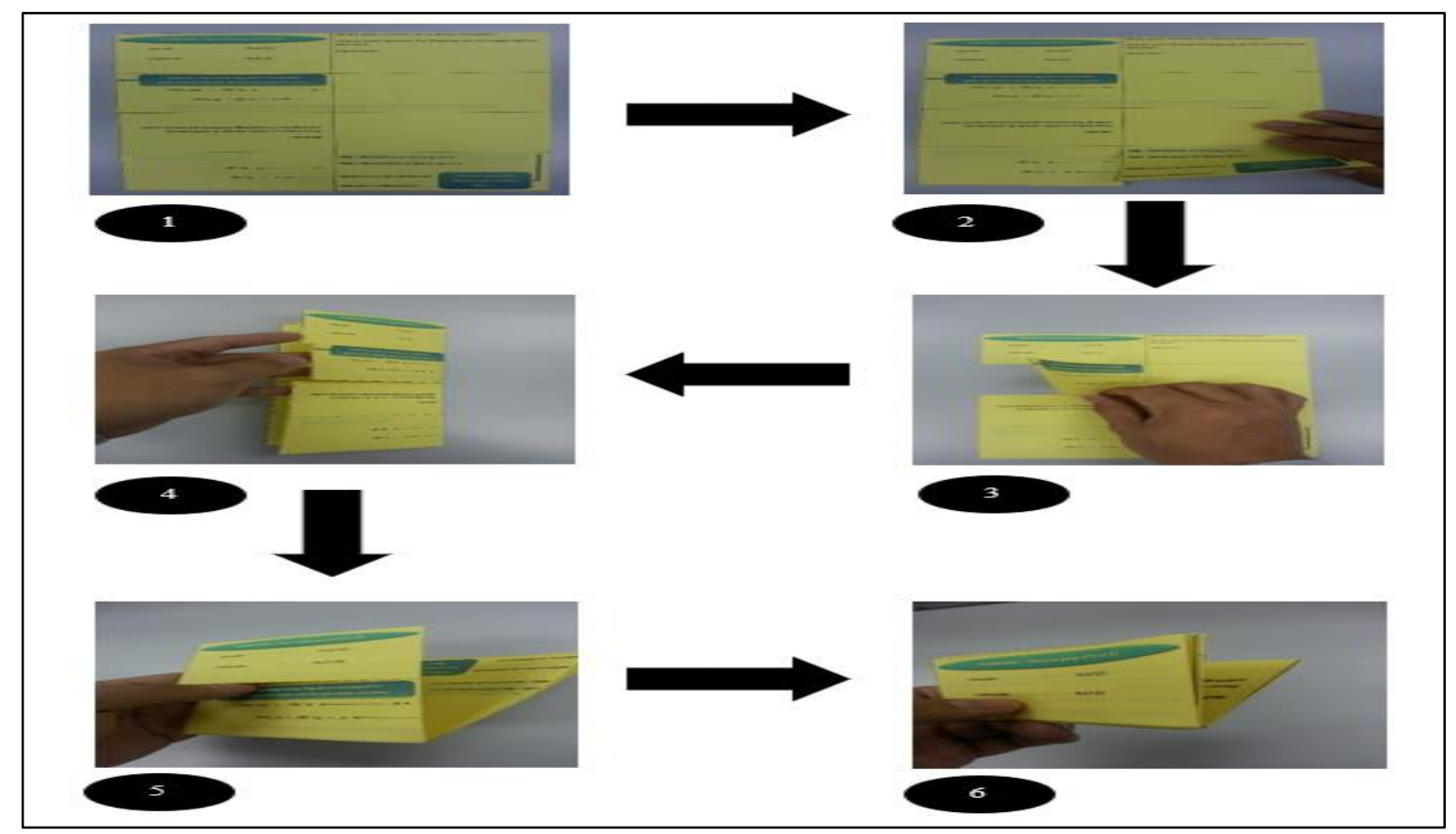

\subsection{FLEMONIC Compartment \#1}

As shown in Figure 4 - the mnemonics of "OIL RIG", "RED CAT" and "AN OX" were presented to the students. These mnemonics stood for - OIL: Oxidation Is Losing of Electrons; RIG: Reduction Is Gaining of Electrons; RED CAT: REDuction is at CAThode; AN OX: ANode is for OXidation. Therefore, by referring to these mnemonics the students should be able to fill in the FLEMONIC Compartment with - " $\rightarrow \mathrm{e}^{-}$" at the Anode and "+ $\mathrm{e}^{-}$ $\rightarrow$ " at the Cathode ( $\mathrm{e}^{-}=$electron). 
Figure 4: FLEMONIC Compartment \#1

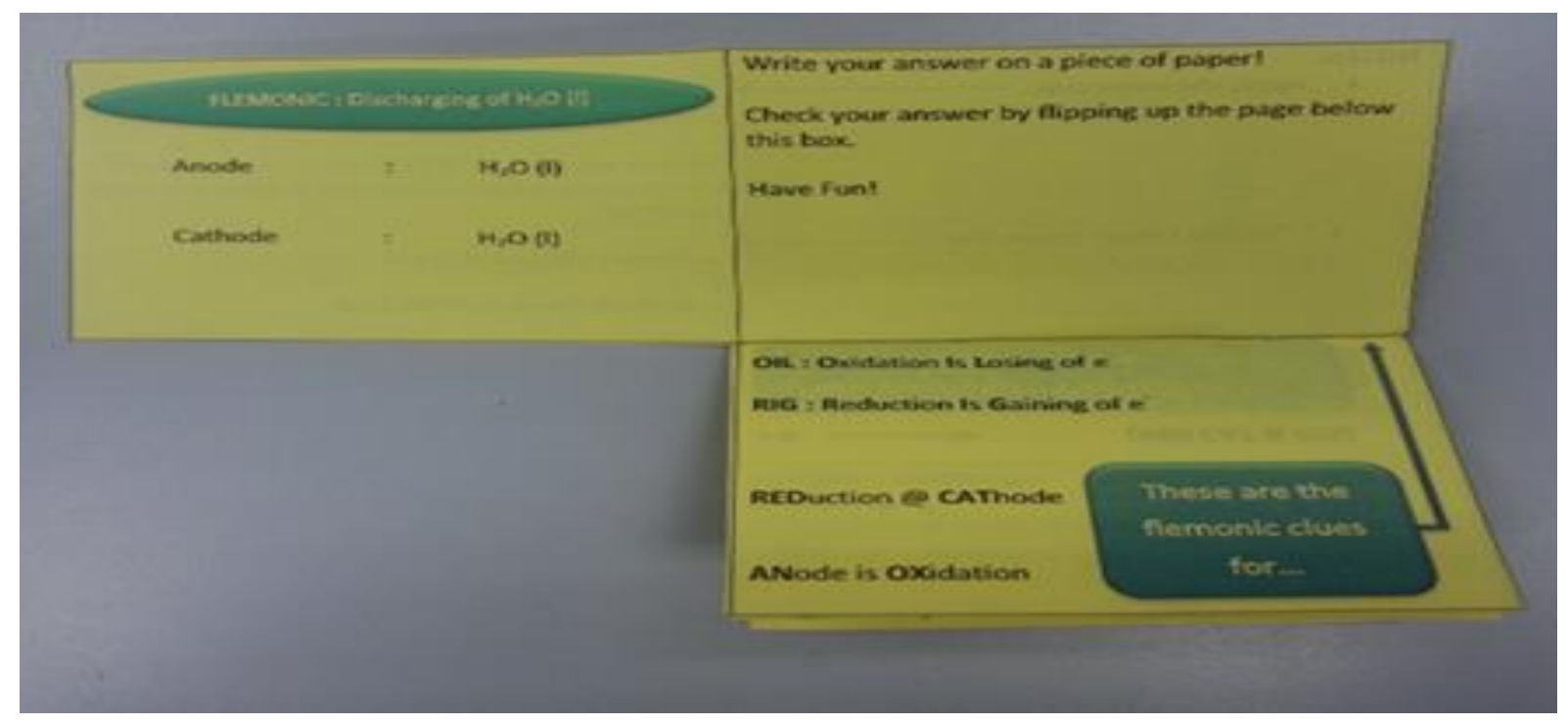

\subsection{FLEMONIC Compartment \#2}

As shown in Figure 5 - the correct answers to the first FLEMONIC Compartment were provided in the second FLEMONIC Compartment along with several blank spaces of which the experimental group had to fill with appropriate answers. The "Middle Letter = Gas" mnemonic was presented to the experimental students to help them in figuring out the correct gaseous products at the Anode and the Cathode, i.e., an[0]de gave them the idea that "Oxygen, $\boldsymbol{O}_{2}$ " gas was liberated at the Anode and cat[H]ode gave them the idea that "Hydrogen, $\mathrm{H}_{2}$ " gas was liberated at the Cathode.

Figure 5: FLEMONIC Compartment \#2

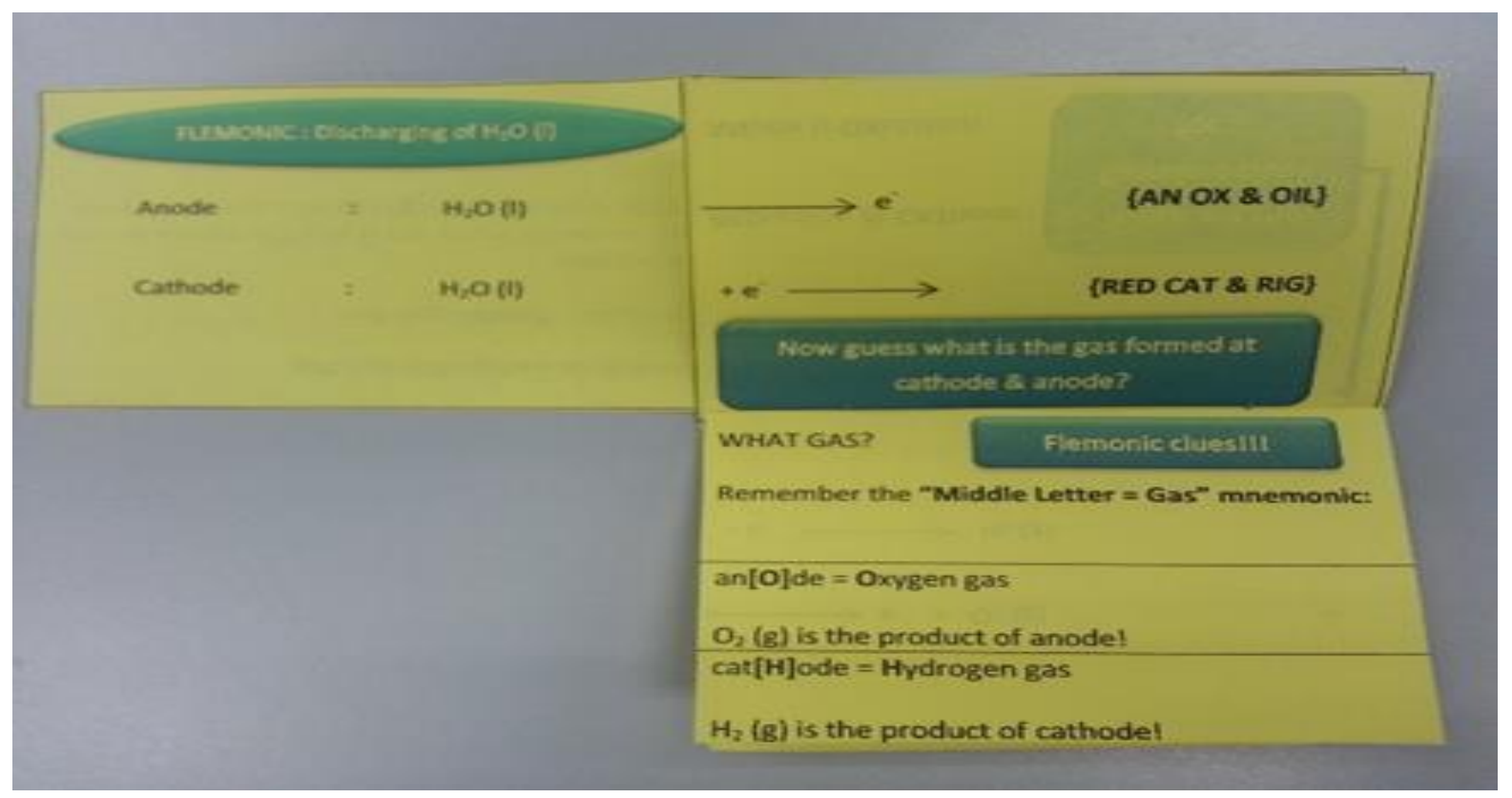

\subsection{FLEMONIC Compartment \#3}

As shown in Figure 6 - for the third FLEMONIC Compartment, the students needed to fill in the blanks at the Anode and the Cathode with acidic $\mathrm{H}^{+}$(aq) and $\mathrm{OH}^{-}$(aq) respectively. 
Thus, they were hinted with this mnemonic - "Remember! [A]node... A is The First Letter for [A]cidic". By knowing this, the experimental students would be able to make

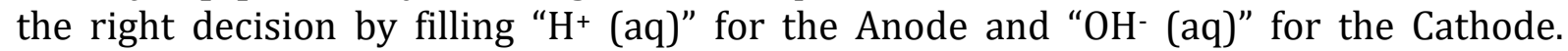
Additionally, the students could use this mnemonic - "Remember! Cat[HO]de... HO Looks Like OH; OH- (aq) @ Cathode".

Figure 6: FLEMONIC Compartment \#3

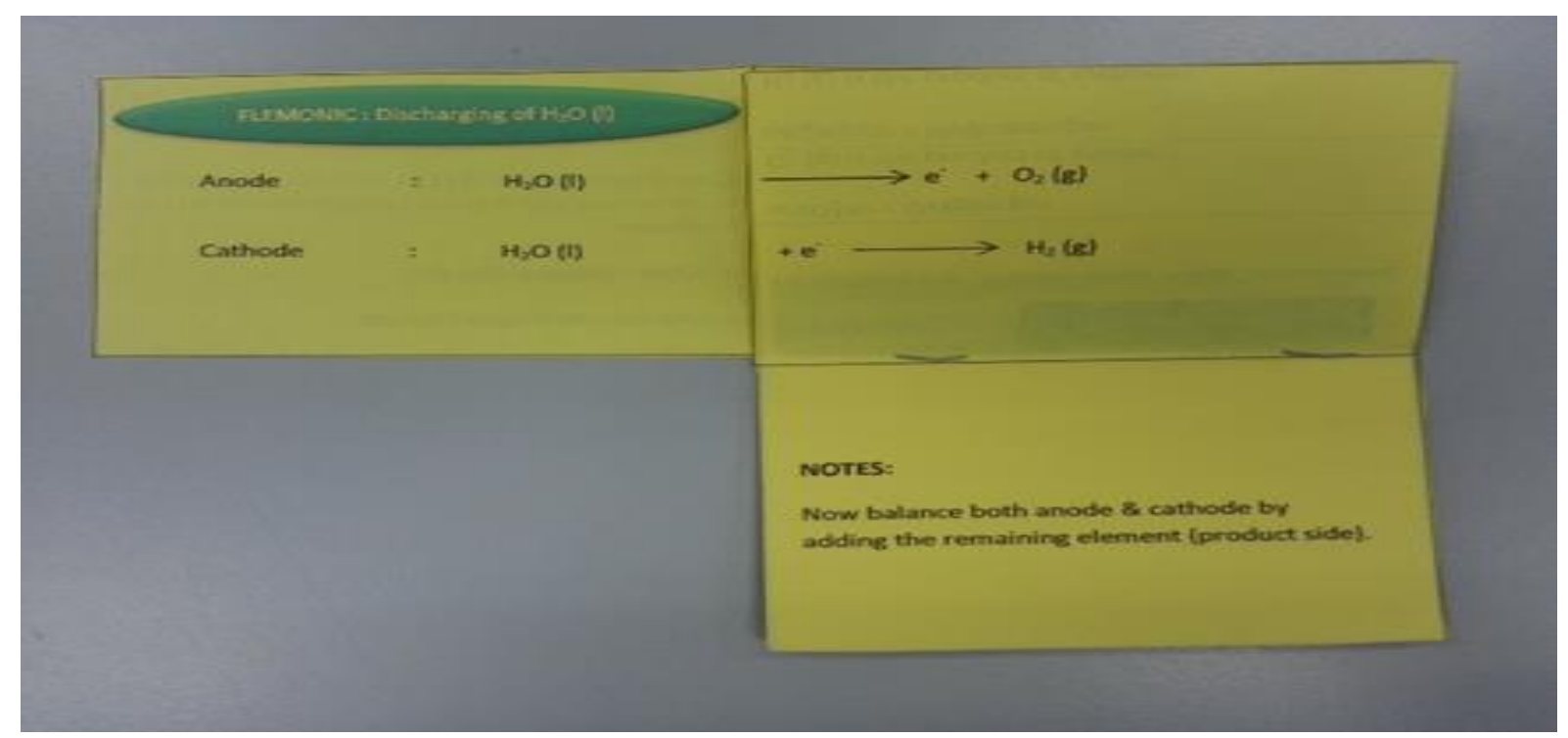

\subsection{FLEMONIC Compartment \#4}

As shown in Figure 7 - this was the last compartment with blank spaces for the students to fill in with answers. They were instructed to do a simple balancing of chemical equations to complete the redox reaction equations for the Anode and the Cathode.

Figure 7: FLEMONIC Compartment \#4

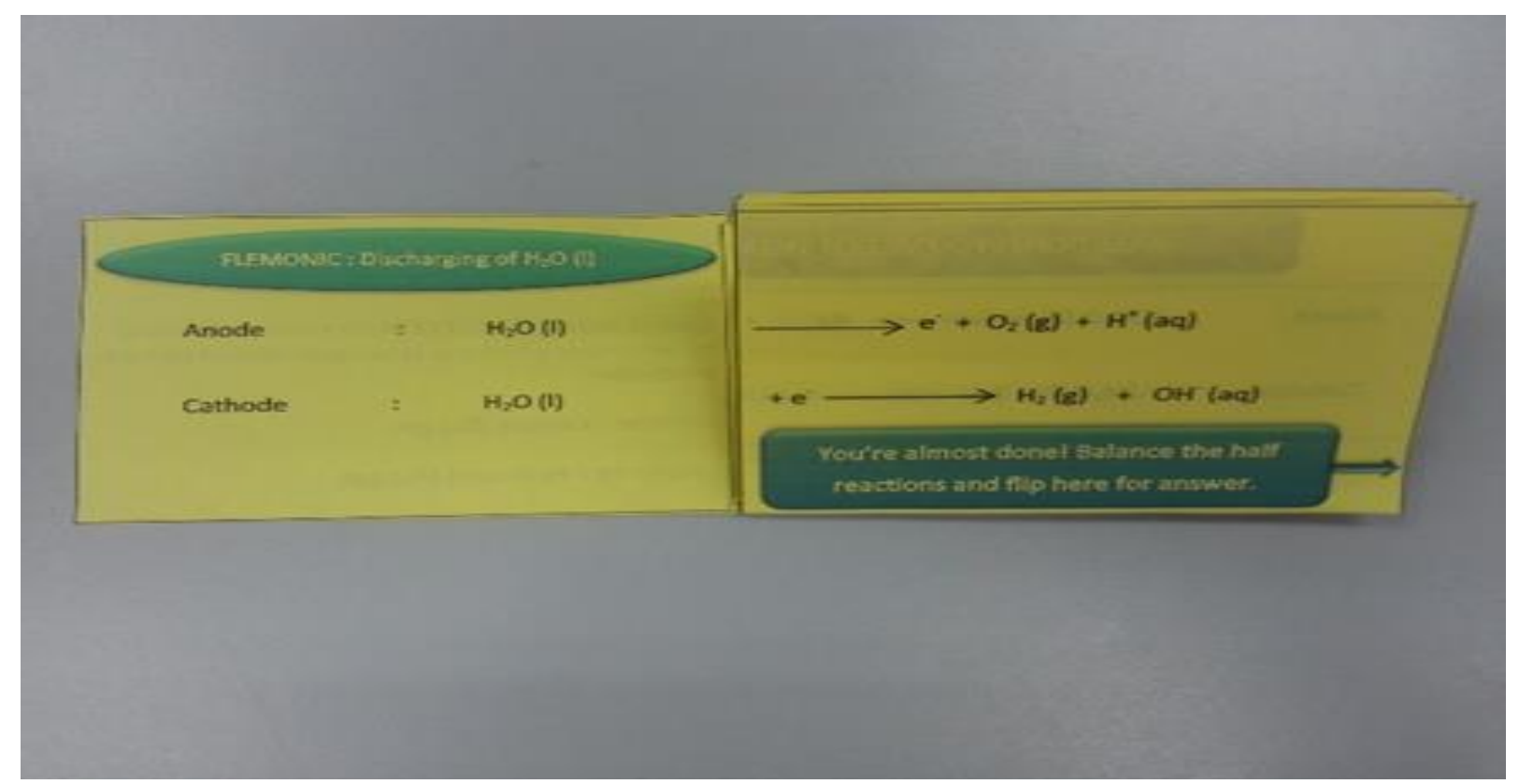




\subsection{FLEMONIC Compartment \#5}

As shown in Figure 8 - this was the last compartment in the FLEMONIC whereby it showed the final (and balanced) anode and cathode half-equations. Students used this compartment to verify their answers. Figure 9 presents the correct redox equations and marking scheme.

Figure 8: FLEMONIC Compartment \#5

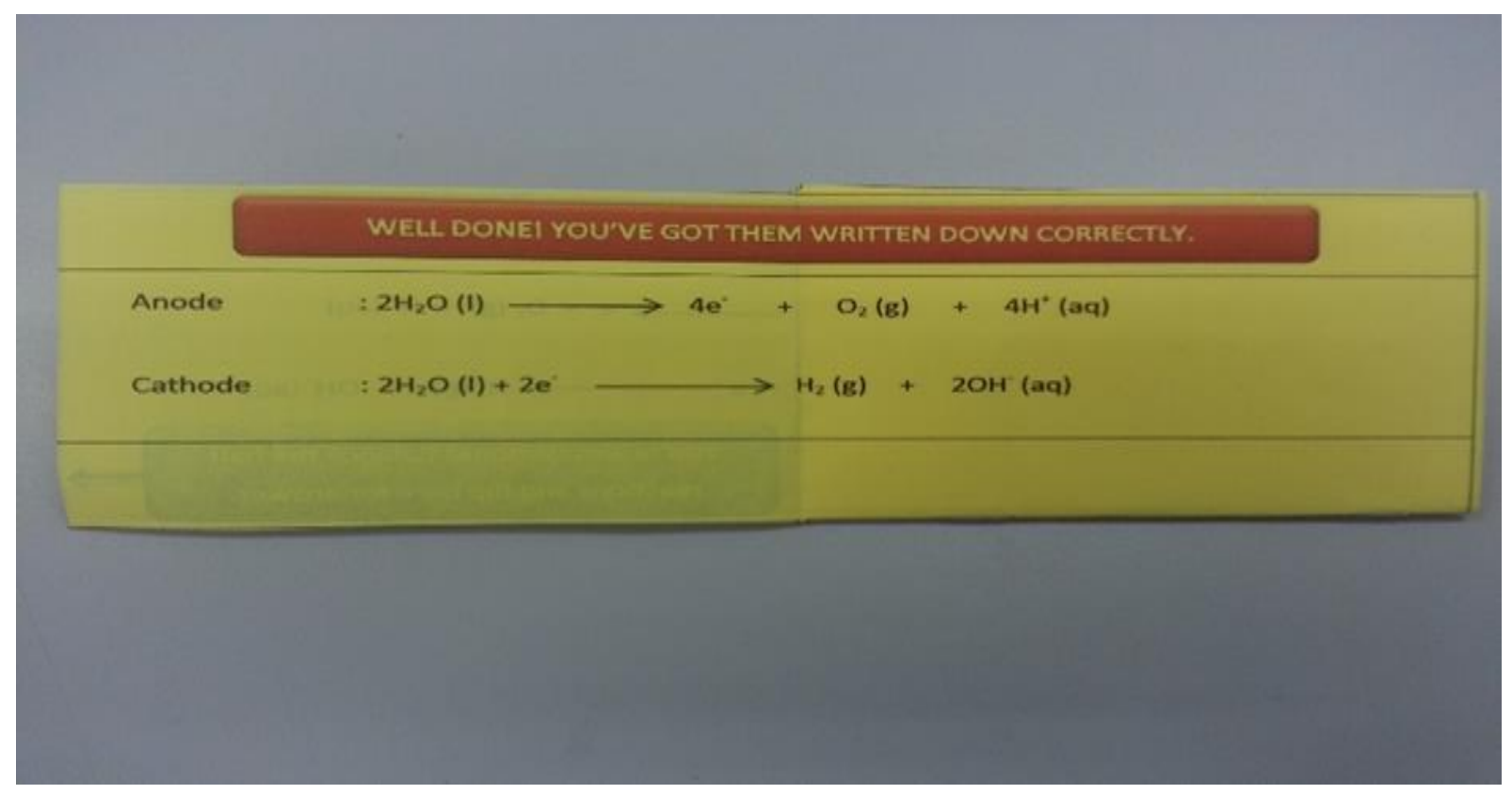

Figure 9: Marking Scheme for The FLEMONIC Study

\section{MARKING SCHEME FOR THE FLEMONIC INVESTIGATION}

The Redox Equations for The Discharging of $\mathrm{H}_{2} \mathrm{O}$ (l) of An Electrolytic Cell:

\begin{tabular}{lll} 
& & $1 \mathrm{M}$ \\
Anode & $: 2 \mathrm{H}_{2} \mathrm{O}(\mathrm{l}) \rightarrow 4 \mathrm{e}^{-}+\mathrm{O}_{2}(\mathrm{~g})+4 \mathrm{H}^{+}(\mathrm{aq})$ & \\
Cathode & $: 2 \mathrm{H}_{2} \mathrm{O}(\mathrm{l})+2 \mathrm{e}^{-} \rightarrow \mathrm{H}_{2}(\mathrm{~g})+2 \mathrm{OH}^{-}(\mathrm{ag})$ & $1 \mathrm{M}=1$ Mark \\
\hline Overall & $: 2 \mathrm{H}_{2} \mathrm{O}(\mathrm{aq}) \rightarrow \mathrm{O}_{2}(\mathrm{~g})+2 \mathrm{H}_{2}(\mathrm{~g})$ & $1 \mathrm{M}$ \\
\hline
\end{tabular}

- " $1 \mathrm{M}$ " is awarded to the species that is written correctly in terms of notation, the correct (balanced) stoichiometric coefficient and the correct phase.

- Another " $1 \mathrm{M}$ " is awarded to writing of "anode" and "cathode" half reactions (balanced).

- Another " $1 \mathrm{M}$ " is awarded to the writing of "overall" equation (balanced).

- Full mark is "13M" (13 Marks). 


\section{Result \& Discussion}

The cognitive objective of the investigation was to improve the students' information retention on the discharging of $\mathrm{H}_{2} \mathrm{O}(l)$ for electrolysis. Consequently, the statistical outcome had to conform to such objective, i.e., to yield a significant difference between two (2) means. Spatz (2008) in their book explains T-Test as a statistical examination of two population means. An independent 2-sample T-Test (Levene's Test) examines whether two samples are different is commonly used when the variances of two normal distributions are unknown and when an experiment involves a small sample size. Therefore, since this investigation involved a small sample of 34 students (17 experimental students and 17 control students) a T-Test analysis was administered by using IBM SPSS to disprove the posited null hypothesis $\left(\mathrm{H}_{0}\right)$.

Pre-test scores from both groups were homogenous according to the T-Test analysis. The control group's pre-test mean score was 3.65\% (minimum $=0 \%$, maximum $=$ $23.0 \%$, standard deviation $=6.71$ ). The experimental group's pre-test mean score was 8.18\% (minimum $=0 \%$, maximum $=23.0 \%$, standard deviation $=8.73$ ). Homogeneity was proven when the mean difference of $4.53 \%$ was insignificant as the T-Test revealed $\mathrm{t}=1.696$ and $p=0.100(p>0.05)$.

For this classroom research, the teacher-researchers harvested the data of score differences $\left(\Delta_{\text {score }}=\right.$ post-test score - pre-test score $)$ from both groups. The control group's mean $\Delta_{\text {score }}$ was $10.0 \%$ (standard deviation $=18.48$ ) and the experimental group obtained a mean $\Delta_{\text {score }}$ of $38.0 \%$ (standard deviation $=30.34$ ). Table 1 summarises the outcomes of the T-Test (Levene's Test) for the post-test.

Table 1: Independent T-Test Analysis of the Difference in the Mean Score Differences between Control Group and Experimental Group

\begin{tabular}{lclllll}
\hline TEST & N & $\begin{array}{l}\text { Mean Score } \\
\text { Differences }\end{array}$ & $\begin{array}{l}\text { Standard } \\
\text { Deviation }\end{array}$ & $\begin{array}{l}\text { Mean } \\
\text { Difference }\end{array}$ & t value & Sig. \\
\hline $\begin{array}{l}\text { Experimental } \\
\text { Group }\end{array}$ & 17 & 38.00 & 30.34 & & & \\
$\begin{array}{l}\text { Control } \\
\text { Group }\end{array}$ & 17 & 10.00 & 18.48 & 28.00 & 3.25 & 0.003 \\
\hline
\end{tabular}

*Significant $p<0.05$

From the analysis of Table 1, the mean score differences of both groups are significantly different as the p-value for the FLEMONIC investigation is $0.003<0.05$. Therefore, the proven heterogeneity in the means of both groups is sufficient to disprove the posited null hypothesis $\left(\mathrm{H}_{0}\right)$; "FLEMONIC: Discharging of $\mathrm{H}_{2} \mathrm{O}(\mathrm{l})$ " cannot strengthen chemistry students' declarative knowledge and thus it does not help the students to memorise the redox equations of $\mathrm{H}_{2} \mathrm{O}(I)$ electrolysis. The data revealed that in the control group there were three (3) students who obtained negative $\Delta_{\text {score }}$ (two -8.0's and one -15.0) whereas in the experimental group only one student obtained a $\Delta_{\text {score }}$ of -7.0. Furthermore, there were students who obtained a $\Delta_{\text {score }}$ of 0.0 in both groups (post-test score $=$ pre-test score), i.e., five (5) students from the control group and only one (1) student from the experimental group. Fifteen (15) experimental students managed to showcase positive performances with the best performance gaining a $\Delta_{\text {score }}$ of +92.0 . On the other hand, only nine (9) control students showcased positive performances and the highest performance obtained a $\Delta_{\text {score }}$ of +62.0 . 


\section{Conclusion}

Due to its nature as classroom research, the investigation was conducted within the boundary of limitations. Firstly, the research was limited to the scope of chemistry students from the Matriculation Programme of the Malaysia Ministry of Education. Secondly, it was limited to the scope of studying the effectiveness of FLEMONIC to enhance students' memory on the discharging of $\mathrm{H}_{2} \mathrm{O}(I)$ for an electrolytic cell. Ergo, it did not go beyond the lowest "remembering" cognitive domain (Forehand, 2010).

"FLEMONIC: Discharging of $\mathrm{H}_{2} \mathrm{O}(I)$ " has been verified to be a good T\&L tool to improve the teacher-researchers' chemistry students' information retention ability. It is substantiated by the quantitative analysis of the harvested data. Thus, the students who were exposed to the designed intervention had experienced a better stimulus for the edification of their declarative knowledge on the subject matter. By tying this notion to neuroscience, it is exciting to extrapolate that the ability of the experimental students to outshine their control counterparts is a manifestation of a better neurological change in their brains, i.e., thickening of myelin sheaths (Fields, 2008). The project spurred an inspiration to revamp note-taking. Some of the students had created their own FLEMONIC for other subjects such as biology, computer science, physics, and mathematics. To conclude, FLEMONIC was more than just a T\&L tool to help with memorisation. It gave a renewed sense of learning to the teacher-researchers and the students.

\section{Acknowledgement}

The teacher-researchers wish to extend their thanks to the family of chemistry lecturers at Labuan Matriculation College for their endless support.

\section{Funding}

This study received no funding.

\section{Conflict of Interests}

The authors declare no conflict of interest in this study.

\section{References}

Aljandali, A. (2016). Quantitative analysis and IBM® SPSS® statistics. Springer International Publishing.

Blankertz, L. (1998). The value and practicality of deliberate sampling for heterogeneity: A critical multiplist perspective. The American Journal of Evaluation, 19(3), 307324. https://doi.org/10.1016/S1098-2140(99)80214-8

Esch, T., \& Stefano, G. B. (2004). The neurobiology of pleasure, reward processes, addiction and their health implications. Neuroendocrinology Letters, 25(4), 235251.

Fields, R. D. (2008). White matter in learning, cognition and psychiatric disorders. Trends in Neurosciences, 31(7), 361-370. https://doi.org/10.1016/j.tins.2008.04.001 
Forehand, M. (2010). Bloom's Taxonomy. Emerging Perspectives on Learning, Teaching, and Technology, 41(4), 47-56.

Johnstone, A. H. (2000). Teaching of chemistry-logical or psychological?. Chemistry $\begin{array}{llll}\text { Education Research and Practice, 1(1), } & \text { 9-15. }\end{array}$ https://doi.org/10.1039/A9RP90001B

Kandel, E. R. (2001). The molecular biology of memory storage: a dialogue between genes and synapses. Science, 294(5544), 1030-1038. https://doi.org/10.1126/science.1067020

Kringelbach, M. L., \& Berridge, K. C. (2009). Towards a functional neuroanatomy of pleasure and happiness. Trends in Cognitive Sciences, 13(11), 479-487. https://doi.org/10.1016/j.tics.2009.08.006

Leamnson, R. (2000). Learning as biological brain change. Change: The Magazine of Higher Learning, 32(6), 34-40.

Mart, C. T. (2013). A passionate teacher: Teacher commitment and dedication to student learning. International Journal of Academic Research in Progressive Education and Development, 2(1), 437-442

Matriculation Division. (2020). Chemistry SK015 \& SK025 curriculum specification [Fact sheet]. Ministry of Education Malaysia.

Merriam-Webster. (n.d.). Addiction. In Merriam-Webster.com dictionary. Retrieved Mac 4, 2021, from https://www.merriam-webster.com/dictionary/addiction

Moon, J. A. (2004). Reflection and employability (Vol. 4). York: LTSN Generic Centre.

Spatz, C. (2008). Tales of distributions: Basic statistics. Thomas.

Squire, L. R., \& Zola, S. M. (1996). Structure and function of declarative and nondeclarative memory systems. Proceedings of the National Academy of Sciences, 93(24), 13515-13522. https://doi.org/10.1073/pnas.93.24.13515 